\title{
Spatial dependency and correlation of properties of soil cultivated with oil palm, Elaeis guineensis, in agroforestry systems in the eastern Brazilian Amazon
}

\author{
Camila Santos da SILVA ${ }^{1}$, Bruno Araujo Furtado de MENDONÇA ${ }^{1}$, Marcos Gervasio PEREIRA ${ }^{2 *}$, \\ Emanuel José Gomes de ARAÚJO'1, Débora Christina CASTELLANI ${ }^{3}$ \\ Universidade Federal Rural do Rio de Janeiro, Instituto de Floresta, Departamento de Silvicultura, Seropédica, Rio de Janeiro, Brasil \\ Universidade Federal Rural do Rio de Janeiro, Instituto de Agronomia, Departamento de Solos, Seropédica, Rio de Janeiro, Brasil \\ Natura Inovação e Tecnologia de Produtos Ltda, Cajamar, São Paulo, Brasil \\ Corresponding author: mgervasiopereira01@gmail.com
}

\begin{abstract}
Geostatistics is a tool that can be used to produce maps with the distribution of nutrients essential for the development of plants. Therefore, the present study aimed to analyze the spatial variation in chemical attributes of soils under oil palm cultivation in agroforestry systems in the eastern Brazilian Amazon, and their spatial dependence pattern. Sixty spatially standardized and georeferenced soil samples were collected at each of three sampling sites (DU1, DU2, and DU3) at 0-20 cm depth. Evaluated soil chemical attributes were $\mathrm{pH}, \mathrm{Al}^{3+}, \mathrm{H}+\mathrm{Al}, \mathrm{K}^{+}, \mathrm{Ca}^{2+}, \mathrm{Mg}^{2+}$, cation exchange capacity $(\mathrm{CEC}), \mathrm{P}$, and organic matter $(\mathrm{OM})$. The spatial dependence of these variables was evaluated with a semivariogram analysis, adjusting three theoretical models (spherical, exponential, and Gaussian). Following analysis for spatial dependence structure, ordinary kriging was used to estimate the value of each attribute at non-sampled sites. Spatial correlation among the attributes was tested using cokriging of data spatial distribution. All variables showed spatial dependence, with the exception of $\mathrm{pH}$, in one sampling site (DU3). Highest $\mathrm{K}^{+}, \mathrm{Ca}^{2+}, \mathrm{Mg}^{2+}$, and OM levels were found in the lower region of two sampling sites (DU1 and DU2). Highest levels of $\mathrm{Al}^{3+}$ and $\mathrm{H}+\mathrm{Al}$ levels were observed in the lower region of sampling site DU3. Some variables were correlated, therefore cokriging proved to be efficient in estimating primary variables as a function of secondary variables. The evaluated attributes showed spatial dependence and correlation, indicating that geostatistics may contribute to the effective management of agroforestry systems with oil palm in the Amazon region.
\end{abstract}

KEYWORDS: cokriging, ordinary kriging, semivariogram, soil properties

\section{Dependência espacial e correlação das propriedades do solo cultivado com dendezeiro, Elaeis guineensis, em sistemas agroflorestais na Amazônia Oriental}

\section{RESUMO}

A geoestatística é uma ferramenta utilizada para produzir mapas de distribuiçâo de nutrientes essenciais para o desenvolvimento das plantas. O presente estudo teve como objetivo analisar a variaçáo espacial dos atributos químicos do solo sob cultivo de dendê em sistemas agroflorestais na Amazônia Oriental brasileira, e seu padrão de dependência espacial. Sessenta amostras de solo espacialmente padronizadas e georreferenciadas foram coletadas em cada um de três locais de amostragem (UD1, UD2 e UD3), na profundidade de $0-20 \mathrm{~cm}$. Os atributos químicos do solo avaliados foram: $\mathrm{pH}, \mathrm{Al}^{3+}, \mathrm{H}+\mathrm{Al}, \mathrm{K}^{+}, \mathrm{Ca}^{2+}, \mathrm{Mg}^{2+}$, capacidade de troca catiônica do solo (CTC), P e matéria orgânica $(\mathrm{MO})$. A dependência espacial dos atributos foi avaliada com análise semivariográfica, ajustando-se três modelos teóricos (esférico, exponencial e gaussiano). Após a análise de dependência espacial, a krigagem ordinária foi empregada para estimar os valores de cada atributo em locais não amostrados. A correlação espacial entre os atributos foi testada utilizando a cokrigagem para espacialização dos dados. Todas as variáveis mostraram dependência espacial, exceto $\mathrm{pH}$ em UD3. Os maiores teores $\mathrm{de} \mathrm{K}^{+}, \mathrm{Ca}^{2+}, \mathrm{Mg}^{2+}$ e $\mathrm{MO}$ foram encontrados na regiáo mais baixa da paisagem, em UD1 e UD2. Os maiores teores de $\mathrm{Al}^{3+}$ e $\mathrm{H}+\mathrm{Al}$ foram observados na região mais baixa da paisagem, em UD3. Algumas variáveis foram correlacionadas, portanto a cokrigagem mostrou-se eficiente na estimativa das variáveis primárias em função das secundárias. Os atributos avaliados mostraram dependência e correlaçáo espacial, indicando que a geoestatística pode contribuir para o manejo efetivo de sistemas agroflorestais com dendê na regiáo amazônica.

PALAVRAS-CHAVE: cokrigagem, krigagem ordinária, semivariograma, propriedades do solo 


\section{INTRODUCTION}

The cultivation of the oil palm (Elaeis guineensis Jacq.) began in the Amazon region in the mid-1940s, as it was considered economically feasible in the edaphoclimatic conditions in the region (Silva et al. 2011). Presently, the state of Pará, in the eastern Brazilian Amazon, is the largest producer of oil palm in Brazil, and its northeastern mesoregion features the highest yield (Ribeiro et al. 2010). Oil palm trees are usually produced in conventional monoculture, however, there is evidence to support that oil palms can be produced in agroforestry systems (AFSs) in combination with other agricultural and silvicultural species (Santiago et al. 2013). This crop combination can contribute to the increase of income in family agriculture (Santiago et al. 2013), recovery of degraded areas, and increase in plant cover, consequently protecting the soil and reducing the emission of greenhouse gases in the Amazon region.

Oil palms have rapid annual growth and demand high levels of nutrient stocks in the soil or replenishment through soil fertilization, so that the evaluation of soil fertility is essential to improve oil palm cultivation and crop productivity (Bernardi et al. 2015). According to the same authors, soil attributes can vary spatially on a reduced geographical scale due to factors such as soil formation, management techniques, fertilization and crop rotation. Therefore, the analysis of the spatial variability of soil attributes on the scale of the plantation area is important for adequate soil management.

One of the most important tools used to determine the spatial variability of soil properties is geostatistics (Cavalcante et al. 2011), which allows an unbiased inference, with minimal variability of soil attributes, to characterize unsampled areas. Interpolation methods are used to construct distribution maps of the variables of interest. Kriging is a geostatistical method that estimates a certain variable in unsampled sites by extrapolation from sampled sites. Another geostatistical method is cokriging, which can be used in cases in which there is a spatial correlation between two or more variables being estimated concomitantly (Yamamoto and Landim 2013).

Geostatistics has already been employed in studies of soil attribute distribution in the Amazon region. In an evaluation of the physical attributes of a Latosol under native forest and pasture in the central Amazon, the methodology was used to show that attribute variability was lower under pasture than under forest, and that the removal of the native forest for pasture implantation interfered with the natural distribution of soil physical attributes (Aquino et al. 2014). Geostatistics was also used to analyze the spatial distribution of soil nutrients in a Latosol under native forest with Brazil nuts trees in the Tapajós National Forest (FLONA Tapajós), in the eastern Brazilian Amazon (Guerreiro et al. 2017).

The hypothesis of this study is that the chemical properties of the soil are spatially dependent and correlated with each other in oil palm cultivation in agroforestry systems. The objective of this study was to analyze the spatial dependence and correlation of the chemical attributes of soils cultivated with oil palm trees in three agroforestry systems in the eastern Brazilian Amazon.

\section{MATERIAL AND METHODS}

The study was conducted in three agroforestry systems, approximately 6 ha each, called demonstrative units (DU1, DU2, and DU3), in which each unit has a different management. The sampling sites were located within each DU. The area is located in the municipality of Tomé-Açu, in the northeastern region of Pará state, in the eastern Brazilian Amazon region (Figure 1). According to the classification of Köppen, the climate of the region is mesothermic and humid (Ami), with regular rainfall without a uniform distribution throughout the year. Annual averages are rainfall 2,300 mm rainfall, $26^{\circ} \mathrm{C}$ temperature, and $85 \%$ relative humidity. In DU1 and DU2 the soil is Yellow Argisol and in DU3 is Yellow Latosol (Santos et al 2013). The topography of the region varies from flat to smooth wavy (slope $\leq 8 \%$ ).

The demonstrative units were implemented in 2008 with oil palm as the main crop, and each DU had a distinct history of land use. DU1 was an abandoned orchard, DU2 had been a 9 to 10 -year-old poultry system, and DU3 contained degraded pasture. The AFS in DU1 was planted with oil palm, açaí (Euterpe oleracea Mart.), bacaba (Oenocarpus bacaba Mart.), banana (Musa spp.), cocoa (Theobroma cacao L.), ipê (Tabebuia spp.), jatobá (Hymenaea courbaril L.), manioc (Manihot esculenta subsp. esculenta (Crantz)), pracaxi (Pentaclethra macroloba (Willd.) Kuntze) and ucuuba (Virola surinamensis (Rol. ex Rottb.) Warb.). In DU2 the AFS was composed of oil palm, açaí, bacaba, banana, cocoa, guanandi (Calophyllum brasiliensis Cambess.), ipê, manioc, and white tachi (Sclerolobium paniculatum Vogel). DU3 was planted with oil palm, bacaba, banana, cacao, cedar (Cedrela spp.), manioc, passion fruit (Passiflora spp.), and pepper (Piper spp.).

A spatially standardized sampling method was used, with $30 \times 30-\mathrm{m}$ spacing between sampling points, totaling 60 sampling points in each DU. The soil samples were collected at a depth of $0-20 \mathrm{~cm}$. Each sampling point was georeferenced using GPS navigation. Soil samples were taken to the Soil Fertility Laboratory of Universidade Estadual Paulista. The following parameters were determined for each sample: $\mathrm{pH}$ in $\mathrm{CaCl}_{2}$, aluminum $\left(\mathrm{Al}^{3+}\right)$, potential acidity $(\mathrm{H}+\mathrm{Al})$, potassium $\left(\mathrm{K}^{+}\right)$, calcium $\left(\mathrm{Ca}^{2+}\right)$, magnesium $\left(\mathrm{Mg}^{2+}\right)$, cation exchange capacity (CEC), phosphorus (P), and organic matter (OM).

The correlation between the variables was determined using Microsoft Excel 2013. Descriptive statistics (mean, median, minimum, maximum, standard deviation, and coefficient of variation) were calculated using the R software, version 3.2.5. Box plot graphs were used to identify outliers. The normality assumption was tested using the Shapiro-Wilk test at a level of significance of $5 \%$. In order to find spatial 


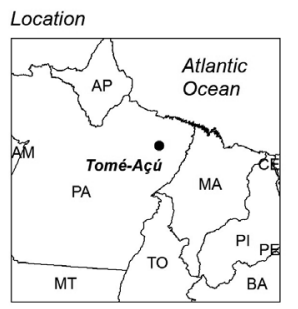

\section{Legend}

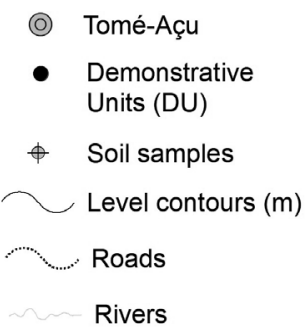

Projection UTM - Zone 22 M Datum SIRGAS2000
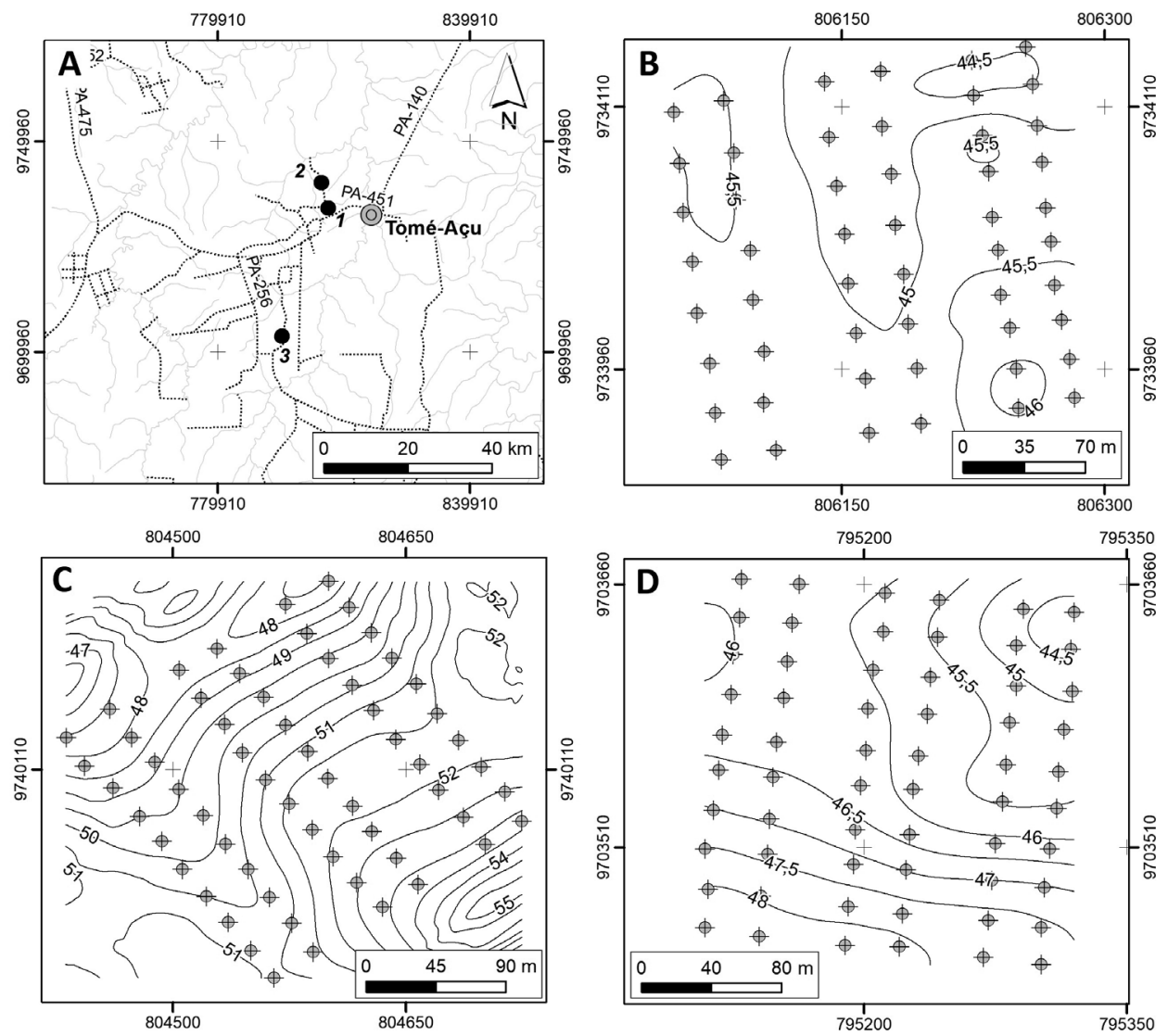

Figure 1. Location of the study areas in Tomé-Açu, Pará state, Brazil (A), demonstrative unit 1 (B), demonstrative unit 2 (C), and demonstrative unit 3 (D).

dependence in the semivariogram, some variables were transformed to the logarithmic scale or discrepant values were removed, as described by Schaffrath $e t$ al. (2008). The spatial dependence of the soil attributes was verified by applying an experimental semivariogram analysis, which was expressed by:

$\gamma(\mathrm{h})=\frac{1}{2 \mathrm{n}(\mathrm{h})} \sum\left(\mathrm{x}_{\mathrm{i}+\mathrm{h}}-\mathrm{x}_{\mathrm{i}}\right)^{2}$

where $\gamma(\mathrm{h})$ is the semivariance of variable $\mathrm{x}_{\mathrm{i}}, \mathrm{h}$ is the distance $(\mathrm{m})$, and $\mathrm{n}$ is the number of experimental pairs of observations $\mathrm{x}_{\mathrm{i}}$ and $\mathrm{x}_{\mathrm{i}+\mathrm{h}}$, separated by a distance $\mathrm{h}$.

After the construction of the experimental semivariogram, the initial parameters "nugget effect," "sill," and "range" were applied to the adjustment of three theoretical models (spherical [2], exponential [3], and Gaussian [4]) using the maximum likelihood estimation. The height that the semivariogram reaches when it levels off is called the sill $\left(\mathrm{C}_{0}+\right.$ $\mathrm{C}$ ), and the distance at which the semivariogram levels off to the sill is called the range (a). The nugget effect $\left(\mathrm{C}_{0}\right)$ is caused by random variance, and a partial sill (C) is called the spatial variance (Yamamoto and Landim 2013).
$\gamma(h)=\left\{\begin{array}{c}C_{0}+C\left[\begin{array}{c}\left.1.5 \frac{h}{a}-0.5\left(\frac{h}{a}\right)^{3}\right] \\ \text { para } h<a \\ C_{0}+C \text { para } h \geq a\end{array}\right.\end{array}\right.$

$\gamma(\mathrm{h})=\mathrm{C}_{0}+\mathrm{C}\left[1-\mathrm{e}^{-\mathrm{h} / \mathrm{a}}\right]$

$\gamma(\mathrm{h})=\mathrm{C}_{0}+\mathrm{C}\left[1-\mathrm{e}^{\left(\frac{\mathrm{h}}{\mathrm{a}}\right)^{2}}\right]$

where $\mathrm{C}_{0}$ is the nugget effect, $\mathrm{C}$ is the contribution, $\mathrm{C}_{0}+\mathrm{C}$ is the sill, and a is the range.

The criteria for the choice of the best semivariance model were the minimum Akaike Information Criterion (AIC), minimum standard error of the estimate (SEE), minimum root mean square error (RMSE), and the lowest degree of spatial dependence (DSD). The DSD was classified as strong (DSD $\leq$ $25 \%)$, moderate $(25 \leq \mathrm{DSD} \leq 75 \%)$, or weak ( $\mathrm{DSD} \geq 75 \%)$. A DSD equal to $100 \%$ suggests a semivariogram with a pure nugget effect (PNE), indicating that the variable is spatially independent (Cambardella et al. 1994). 
After testing the variables for spatial dependence, soil attributes were estimated and spatialized using ordinary kriging [5], in order to construct the maps with the spatial distribution of the variables of interest.

$\mathrm{Z}_{\mathrm{KO}}^{*}\left(\mathrm{x}_{0}\right)=\sum_{\mathrm{i}=1}^{\mathrm{n}} \lambda_{\mathrm{i}}\left[\mathrm{Z}\left(\mathrm{x}_{\mathrm{i}}\right)\right]$

where $Z_{\mathrm{KO}}^{*}\left(\mathrm{x}_{0}\right)$ is the estimate of the unsampled sites, $\mathrm{Z}\left(\mathrm{x}_{\mathrm{i}}\right)$ are the sampled neighboring sites, and $\lambda_{\mathrm{i}}$ are the weights.

The variables were also spatialized by cokriging [6], in which a variable that is difficult to determine (primary variable) was estimated as a function of another variable that was easy to obtain (secondary variable) and was spatially dependent and correlated with the primary variable. The parameters used to choose the theoretical model that best estimated a primary variable as a function of secondary variable were the coefficient of determination $\left(\mathrm{R}^{2}\right)$, SEE, RMSE, and DSD.

$$
\mathrm{Z}_{1}^{*}\left(\mathrm{x}_{0}\right)=\sum_{\mathrm{i}=1}^{\mathrm{n}_{1}} \lambda_{1 \mathrm{i}} \mathrm{Z}_{1}\left(\mathrm{x}_{1 \mathrm{i}}\right)+\sum_{\mathrm{i}=1}^{\mathrm{n}_{2}} \lambda_{2 \mathrm{i}} \mathrm{Z}_{2}\left(\mathrm{x}_{2 \mathrm{i}}\right)
$$

where $\mathrm{Z}_{1}^{*}\left(\mathrm{x}_{0}\right)$ is the primary variable estimate at point $\mathrm{x}_{0} ; \mathrm{Z}_{1}$ and $Z_{2}$ are the primary and secondary variables, respectively; $\mathrm{n}$ is the number of neighbors, and $\lambda_{\mathrm{i}}$ is the weight.

The geostatistical analysis, i.e., the construction of semivariograms, was conducted using R software version 3.2.5, in the geoR package (Ribeiro Júnior and Diggle 2001). Kriging and cokriging were performed in the ArcGIS software version 10.2.

\section{RESULTS}

The $\mathrm{CV}$ values were considered moderate for most variables (Table 1). $\mathrm{P}$ and $\mathrm{Al}^{3+}$ were highly variable at DU1 and DU2, respectively, thus, their minimum and maximum values were considered discrepant for these attributes. Of the variables that were not normally distributed, only P in DU1 and DU3 was log-transformed, because the other variables presented spatial dependence even with non-normality. In addition, the outliers of OM in DU1 (11.39 and $\left.15.81 \mathrm{~g} \mathrm{~kg}^{-1}\right)$, DU2 (12.36, 15.81 and $\left.45.76 \mathrm{~g} \mathrm{~kg}^{-1}\right)$, and DU3 $\left(16.82,17.45,32.81\right.$ and $\left.37.79 \mathrm{~g} \mathrm{~kg}^{-1}\right)$, and $\mathrm{Ca}^{2+}$ and $\mathrm{P}$ in DU2 $\left(45.43 \mathrm{mmol}_{\mathrm{c}} \mathrm{dm}^{-3}\right.$ and 11.00 and 15.00 $\mathrm{mg} \mathrm{dm}^{-3}$, respectively) were excluded from the dataset to improve the spatial dependence of the variables (Supplementary Material, Figures S1 and S2). The inclusion of the outliers resulted in a

Table 1. Descriptive statistics of the chemical characteristics of soil from three study areas (DU1, DU2 and DU3) within agroforestry systems containing oil palm plantations in Tomé-Açu, Pará, Brazil.

\begin{tabular}{|c|c|c|c|c|c|c|c|c|c|}
\hline \multirow{2}{*}{ Statistics } & \multirow{2}{*}{$\mathrm{pH}$} & $\mathrm{Al}^{3+}$ & $\mathrm{H}+\mathrm{Al}$ & $\mathrm{K}^{+}$ & $\mathrm{Ca}^{2+}$ & $\mathrm{Mg}^{2+}$ & CEC & $\mathrm{OM}$ & $P$ \\
\hline & & \multicolumn{6}{|c|}{$\mathrm{mmol}_{c} \mathrm{dm}^{-3}$} & $\mathrm{~g} \mathrm{~kg}^{-1}$ & $m g d^{-3}$ \\
\hline \multicolumn{10}{|c|}{ DU1 } \\
\hline Mean & 4.58 & 1.87 & 41.03 & 0.97 & 22.70 & 5.80 & 70.49 & 32.78 & 16.72 \\
\hline Median & 4.58 & 1.56 & 41.19 & 0.93 & 22.72 & 6.14 & 70.19 & 33.52 & 11.94 \\
\hline Minimum & 4.03 & 0.64 & 29.56 & 0.58 & 9.29 & 1.84 & 54.12 & 11.39 & 7.28 \\
\hline Maximum & 5.09 & 5.04 & 51.12 & 1.51 & 37.17 & 9.51 & 86.28 & 43.95 & 75.13 \\
\hline $\mathrm{SD}^{1}$ & 0.21 & 0.97 & 5.46 & 0.21 & 6.00 & 1.91 & 8.01 & 5.70 & 12.43 \\
\hline $\mathrm{CV}^{2}(\%)$ & 4.55 & 51.65 & 13.30 & 21.94 & 26.43 & 32.92 & 11.36 & 17.40 & 74.33 \\
\hline$W^{3}$ & $0.96^{\mathrm{ns}}$ & $0.00^{*}$ & $0.51^{\mathrm{ns}}$ & $0.09^{\text {ns }}$ & $0.73^{\mathrm{ns}}$ & $0.54^{\mathrm{ns}}$ & $0.48^{\text {ns }}$ & $0.00^{*}$ & $0.00^{*}$ \\
\hline \multicolumn{10}{|c|}{ DU2 } \\
\hline Mean & 4.76 & 1.13 & 33.19 & 1.03 & 26.31 & 6.54 & 67.06 & 31.07 & 6.04 \\
\hline Median & 4.80 & 0.84 & 31.08 & 1.05 & 25.30 & 6.44 & 66.22 & 31.18 & 5.54 \\
\hline Minimum & 4.20 & 0.16 & 22.48 & 0.58 & 17.55 & 4.30 & 50.16 & 12.36 & 4.16 \\
\hline Maximum & 5.20 & 4.24 & 55.03 & 1.75 & 45.43 & 9.51 & 92.97 & 45.76 & 15.00 \\
\hline SD & 0.25 & 0.89 & 7.74 & 0.23 & 5.29 & 1.31 & 8.49 & 5.90 & 1.73 \\
\hline CV (\%) & 5.23 & 78.49 & 23.31 & 22.36 & 20.10 & 20.07 & 12.66 & 19.00 & 28.69 \\
\hline W & $0.05^{\mathrm{ns}}$ & $0.00^{*}$ & $0.00^{*}$ & $0.10^{\mathrm{ns}}$ & $0.01^{*}$ & $0.09^{\mathrm{ns}}$ & $0.51^{\mathrm{ns}}$ & $0.18^{\text {ns }}$ & $0.00^{*}$ \\
\hline \multicolumn{10}{|c|}{ DU3 } \\
\hline Mean & 4.43 & 2.47 & 32.84 & 0.27 & 16.11 & 3.45 & 52.67 & 24.45 & 4.35 \\
\hline Median & 4.41 & 2.32 & 32.50 & 0.20 & 15.47 & 3.47 & 52.20 & 23.93 & 3.85 \\
\hline Minimum & 4.20 & 0.64 & 25.78 & 0.13 & 9.52 & 2.08 & 41.91 & 16.82 & 2.69 \\
\hline Maximum & 4.90 & 4.48 & 43.19 & 0.70 & 35.69 & 6.14 & 77.47 & 37.79 & 11.46 \\
\hline SD & 0.13 & 0.95 & 3.83 & 0.15 & 4.15 & 0.83 & 5.90 & 3.48 & 1.66 \\
\hline CV (\%) & 2.89 & 38.32 & 11.65 & 56.12 & 25.75 & 24.19 & 11.20 & 14.22 & 38.13 \\
\hline W & $0.01^{*}$ & $0.31^{\text {ns }}$ & $0.07^{\mathrm{ns}}$ & $0.00^{*}$ & $0.00^{*}$ & $0.00^{*}$ & $0.00^{*}$ & $0.01^{*}$ & $0.00^{*}$ \\
\hline
\end{tabular}

'Standard Deviation; ${ }^{2}$ Coefficient of variation; ${ }^{3}$ Shapiro-Wilk Test; ${ }^{\text {ns }}$ Not statistically significant; ${ }^{*}$ Significant $(p<0.05)$. 
worse performance of the semivariogram parameters and poorer spatial dependence for OM in DU2 and DU3 (Supplementary Material, Figure S3 and Table S1).

All variables showed spatial dependence (Table 2) except $\mathrm{pH}$ in DU3, which showed a pure nugget effect. The model that best represented the semivariance for most variables in the three study areas was the spherical model, followed by the Gaussian and exponential models (Table 2). Most (88.89\%) variables presented strong to moderate DSD, indicating a good adjustment. Only $\mathrm{Ca}^{2+}$ in DU2 and OM in DU3 presented weak DSD. The range varied from $22.30 \mathrm{~m}\left(\mathrm{Ca}^{2+}\right)$ to 215.17
$\mathrm{m}(\mathrm{P})$ in DU1, $30.61 \mathrm{~m}(\mathrm{OM})$ to $230.61 \mathrm{~m}\left(\mathrm{Al}^{3+}\right)$ in DU2, and $5.78 \mathrm{~m}(\mathrm{pH})$ to $340.96 \mathrm{~m}\left(\mathrm{Al}^{3+}\right)$ in DU3.

In the maps constructed using ordinary kriging (Figures 2, 3 and 4), the distributions of $\mathrm{pH}$ and $\mathrm{Al}^{3+}$ were antagonistic in DU1 and DU2 (Figures 2A and 2B, 3A and 3B), because the two variables were negatively correlated. Accordingly, the areas with the highest levels of $\mathrm{H}+\mathrm{Al}$ (Figures 2C and 3C) had the lowest $\mathrm{pH}$ values.

The highest levels of $\mathrm{K}^{+}, \mathrm{Ca}^{2+}, \mathrm{Mg}^{2+}$, and OM in DU1 and DU2 (Figures 2 and 3) were observed at lower altitudes, although the variability was low. This pattern was not observed

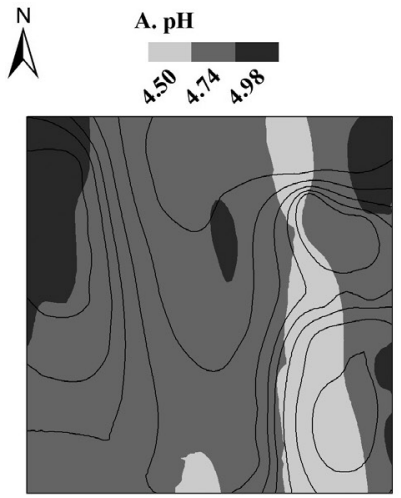

D. $\mathbf{K}^{+}\left(\mathbf{m m o l}_{\mathbf{c}} \mathbf{d m}^{-3}\right)$

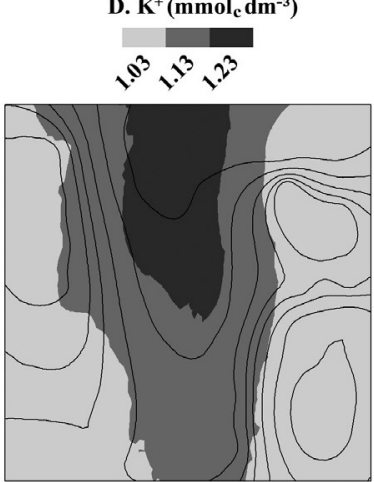

G. CEC $\left(\operatorname{mmol}_{\mathrm{c}} \mathrm{dm}^{-3}\right)$

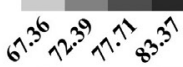

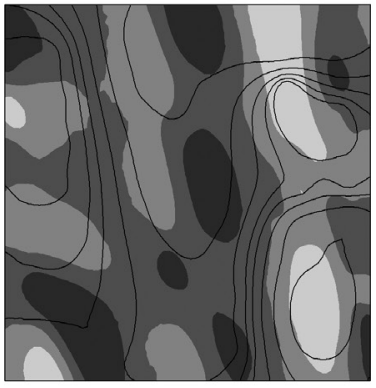

B. $\mathbf{A l}^{3+}\left(\mathbf{m m o l}_{\mathbf{c}} \mathbf{d m}^{-3}\right)$ $a^{5}+0^{9}+x^{3}$

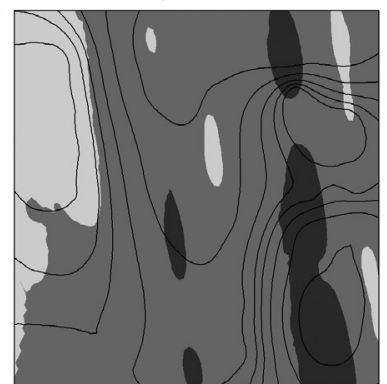

E. $\mathrm{Ca}^{2+}\left(\mathrm{mmol}_{\mathrm{c}} \mathrm{dm}^{-3}\right)$

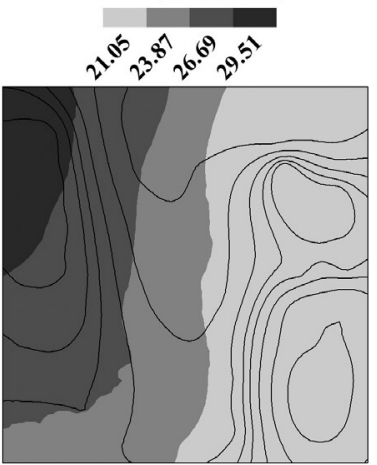

H. OM $\left(\mathrm{g} \mathrm{kg}^{-1}\right)$

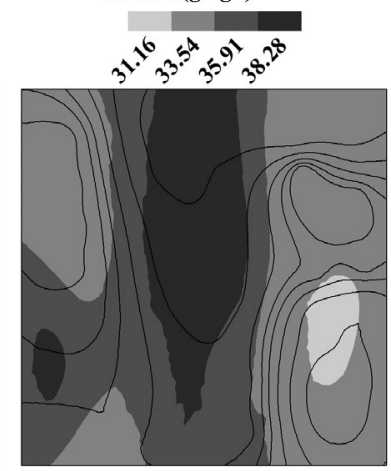

Scale 1:3500

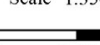

C. $\mathrm{H}+\mathrm{Al}\left(\mathrm{mmol}_{\mathbf{c}} \mathrm{dm}^{-3}\right)$

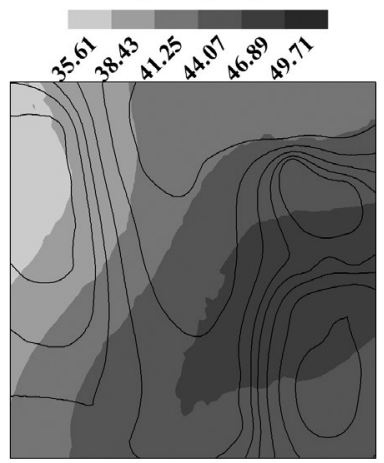

F. $\mathrm{Mg}^{2+}\left(\mathrm{mmol}_{\mathrm{c}} \mathrm{dm}^{-3}\right)$ $x^{9} 62^{6}+3^{60} 89^{60}$

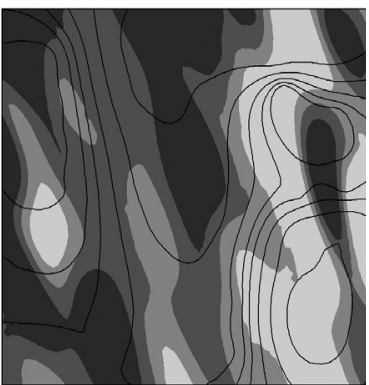

I. $\mathbf{P}\left(\mathrm{mg} \mathrm{dm}^{-3}\right)$

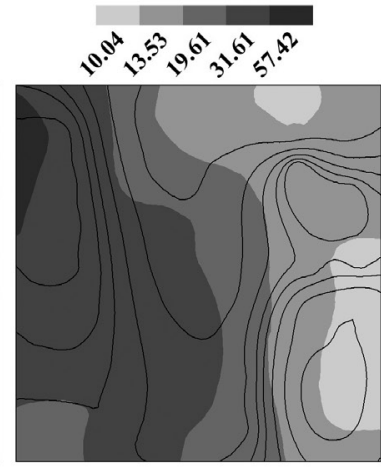

$\begin{array}{llllll} & 0,03 & 0,06 & 0,12 & 0,18\end{array} \quad \mathrm{~km}$

Figure 2. Spatial distribution of the chemical attributes of the soil in the study area in DU1 using ordinary kriging. 
Table 2. Parameters, degree of spatial dependence, and theoretical models adjusted to the chemical characteristics of the soil in three study areas (DU1, DU2 and DU3) within agroforestry systems containing oil palm plantations in Tomé-Açu, Pará, Brazil.

\begin{tabular}{|c|c|c|c|c|c|c|c|c|c|}
\hline \multirow{2}{*}{ Statistics } & \multirow{2}{*}{ pH } & $\mathrm{Al}^{\mid++}$ & $\mathrm{H}+\mathrm{Al}$ & $\mathrm{K}^{+}$ & $\mathrm{Ca}^{2+}$ & $\mathrm{Mg}^{2+}$ & CEC & $\mathrm{OM}$ & $P$ \\
\hline & & \multicolumn{6}{|c|}{$\mathrm{mmol}_{\mathrm{c}} \mathrm{dm}^{-3}$} & $\mathrm{~g} \mathrm{~kg}^{-1}$ & $\mathrm{mg} \mathrm{dm}^{-3}$ \\
\hline \multicolumn{10}{|c|}{ DU1 } \\
\hline $\mathrm{AlC}^{1}$ & -22.02 & 140.02 & 313.11 & -9.82 & 332.99 & 191.23 & 368.25 & 285.62 & 62.16 \\
\hline $\mathrm{SEE}^{2}$ & 0.00 & 0.00 & 0.00 & 0.01 & 0.01 & 0.03 & 0.01 & 0.01 & 0.02 \\
\hline $\mathrm{RMSE}^{3}$ & 0.78 & 0.84 & 1.01 & 0.97 & 0.90 & 0.79 & 1.25 & 1.06 & 1.00 \\
\hline $\mathrm{C}_{0}^{4}$ & 0.00 & 0.00 & 16.19 & 0.03 & 0.00 & 0.00 & 0.00 & 9.66 & 0.07 \\
\hline$\left(C_{0}+C\right)^{5}$ & 0.11 & 0.92 & 37.10 & 0.04 & 34.32 & 3.10 & 60.85 & 17.34 & 0.32 \\
\hline$a^{6}$ & 195.68 & 28.93 & 163.00 & 131.24 & 22.30 & 31.77 & 36.41 & 47.14 & 215.17 \\
\hline $\mathrm{DSD}^{7}(\%)$ & 0.00 & 0.00 & 43.64 & 75.00 & 0.00 & 0.00 & 0.00 & 55.68 & 22.79 \\
\hline Class & $S^{8}$ & $S$ & $\mathrm{M}^{9}$ & M & $S$ & $S$ & $S$ & M & S \\
\hline Model & $S p^{10}$ & $E^{11}$ & $G^{12}$ & Sp & E & G & $\mathrm{Sp}$ & G & $\mathrm{Sp}$ \\
\hline \multicolumn{10}{|c|}{ DU2 } \\
\hline AIC & -3.20 & 147.93 & 401.26 & -9.73 & 353.54 & 203.76 & 419.40 & 343.58 & 165.50 \\
\hline SEE & 0.00 & 0.01 & 0.00 & 0.01 & 0.01 & 0.01 & 0.00 & 0.00 & 0.01 \\
\hline RMSE & 1.00 & 0.99 & 1.00 & 0.96 & 1.00 & 1.00 & 0.99 & 1.00 & 0.97 \\
\hline$C_{0}$ & 0.03 & 0.42 & 21.38 & 0.04 & 17.23 & 1.08 & 32.23 & 14.99 & 0.51 \\
\hline$\left(C_{0}+C\right)$ & 0.06 & 0.85 & 55.34 & 0.06 & 21.81 & 1.69 & 68.93 & 21.89 & 1.13 \\
\hline a & 178.66 & 230.61 & 121.77 & 103.58 & 164.05 & 107.67 & 114.73 & 30.61 & 125.69 \\
\hline DSD (\%) & 51.17 & 49.23 & 38.63 & 64.03 & 78.99 & 63.62 & 46.76 & 68.49 & 44.66 \\
\hline Class & M & M & M & M & $W^{13}$ & M & M & M & M \\
\hline Model & Sp & Sp & Sp & G & $\mathrm{Sp}$ & Sp & Sp & G & $\mathrm{Sp}$ \\
\hline \multicolumn{10}{|c|}{ DU3 } \\
\hline AIC & -69.28 & 156.15 & 330.88 & -70.21 & 343.29 & 146.77 & 388.43 & 269.27 & 11.64 \\
\hline SEE & 0.01 & 0.00 & 0.00 & 0.01 & 0.04 & 0.00 & 0.00 & 0.00 & 0.00 \\
\hline RMSE & 1.13 & 1.00 & 0.94 & 1.10 & 1.00 & 1.06 & 0.99 & 1.00 & 0.95 \\
\hline$C_{0}$ & 0.02 & 0.58 & 11.12 & 0.01 & 13.37 & 0.46 & 24.23 & 5.52 & 0.04 \\
\hline$\left(C_{0}+C\right)$ & 0.02 & 2.02 & 16.14 & 0.02 & 22.54 & 0.69 & 34.73 & 6.49 & 0.11 \\
\hline a & 5.78 & 340.96 & 162.74 & 105.70 & 175.95 & 70.34 & 33.86 & 196.42 & 96.73 \\
\hline DSD (\%) & 100.00 & 28.81 & 68.90 & 32.26 & 59.32 & 66.90 & 69.77 & 84.99 & 41.93 \\
\hline Class & $\mathrm{PNE}^{14}$ & M & M & M & M & M & M & W & M \\
\hline Model & - & G & G & Sp & G & G & G & $S p$ & G \\
\hline
\end{tabular}

Akaike Information Criterion; ${ }^{2}$ Standard error of the estimate; ${ }^{3}$ Root mean square error; ${ }^{4}$ Nugget effect; ${ }^{5}$ Sill; ${ }^{6}$ Range; ${ }^{7}$ Degree of spatial dependence; ${ }^{8}$ Strong; ${ }^{9}$ Moderate; ${ }^{10}$ Spherical; ${ }^{11}$ Exponential; ${ }^{12}$ Gaussian; ${ }^{13}$ Weak; ${ }^{14}$ Pure nugget effect.

in DU3 (Figure 4), where the levels of $\mathrm{Al}^{3+}$ and $\mathrm{H}+\mathrm{Al}$ were higher at lower altitudes.

The estimates only are plausible when the correlations between variables are high (Watanabe et al. 2009). Therefore, we selected correlations that had $\mathrm{R} \geq 0.60$ (Table 3 ). The DSD was considered strong or moderate for all variables and the better-adjusted model was the exponential model, followed by the spherical and Gaussian models.

In the maps containing soil attributes estimated by cokriging, the co-variable with the highest number of correlations was $\mathrm{pH}$. $\mathrm{Al}^{3+}$ was used to estimate $\mathrm{Mg}^{2+}$ (Figure $\left.5 \mathrm{D}\right)$ and $\mathrm{H}+\mathrm{Al}$ (Figure 5I). $\mathrm{Mg}^{2+}$ (Figure 5E), $\mathrm{H}+\mathrm{Al}$ (Figures 5J and 5K), and $\mathrm{OM}$ (Figure 5L) were used to estimate the CEC.

\section{DISCUSSION}

In the case of variables that show no spatial dependence, such as $\mathrm{pH}$ in DU3, it is necessary to sample a larger number of
Table 3. Parameters and adjusted models of semivariograms in three study areas (DU1, DU2 and DU3) in agroforestry systems containing oil palm plantations in Tomé-Açu, Pará, Brazil.

\begin{tabular}{lcccccc} 
Variables & $\mathrm{R}^{1}$ & $\mathrm{R}^{22}$ & $\mathrm{SEE}^{3}$ & $\mathrm{RMSE}^{4}$ & $\mathrm{DSD}^{5}$ & Model \\
\hline & \multicolumn{7}{c}{$\mathrm{DU1}$} \\
\hline $\mathrm{Al} \times \mathrm{pH}$ & -0.92 & 0.85 & 0.38 & 1.49 & 0.00 & Spherical \\
\hline $\mathrm{Ca} \times \mathrm{pH}$ & 0.77 & 0.54 & 3.45 & 1.36 & 0.00 & Exponential \\
\hline $\mathrm{Mg} \times \mathrm{pH}$ & 0.67 & 0.63 & 1.05 & 1.03 & 0.00 & Exponential \\
\hline $\mathrm{Mg} \times \mathrm{Al}$ & -0.68 & 0.57 & 1.30 & 2.16 & 0.10 & Gaussian \\
\hline $\mathrm{CEC} \times \mathrm{Mg}$ & 0.63 & 0.36 & 3.81 & 1.00 & 0.00 & Exponential \\
\hline \multicolumn{7}{c}{$\mathrm{DU} 2$} \\
\hline $\mathrm{Al} \times \mathrm{pH}$ & -0.89 & 0.34 & 0.44 & 0.99 & 45.47 & Gaussian \\
\hline $\mathrm{H}+\mathrm{Al} \times \mathrm{pH}$ & -0.81 & 0.59 & 3.75 & 0.90 & 21.25 & Spherical \\
\hline $\mathrm{Mg} \times \mathrm{pH}$ & 0.61 & 0.19 & 0.53 & 0.99 & 48.84 & Exponential \\
\hline $\mathrm{H}+\mathrm{Al} \times \mathrm{Al}$ & 0.86 & 0.62 & 3.64 & 0.89 & 21.04 & Spherical \\
\hline $\mathrm{CEC} \times \mathrm{H}+\mathrm{Al}$ & 0.70 & 0.48 & 4.32 & 0.98 & 28.97 & Spherical \\
\hline \multicolumn{7}{c}{$\mathrm{DU3}$} \\
\hline $\mathrm{CEC} \times \mathrm{H}+\mathrm{Al}$ & 0.64 & 0.32 & 2.36 & 0.98 & 44.21 & Exponential \\
\hline $\mathrm{CEC} \times \mathrm{OM}$ & 0.71 & 0.53 & 3.05 & 1.06 & 1.97 & Exponential \\
\hline
\end{tabular}

${ }^{1}$ Correlation coefficient; ${ }^{2}$ Determination coefficient; ${ }^{3}$ Standard error of the estimate; ${ }^{4}$ Root mean square error; ${ }^{5}$ Degree of spatial dependence. 


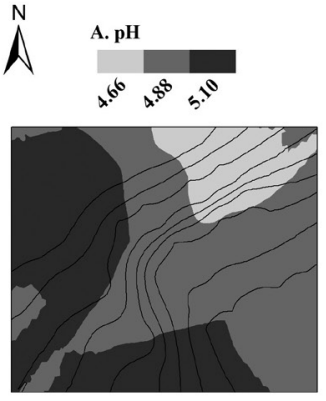

D. $\mathbf{K}^{+}\left(\mathrm{mmol}_{\mathbf{c}} \mathbf{d m}^{-3}\right)$ $0^{6} v^{2} 5^{5}$

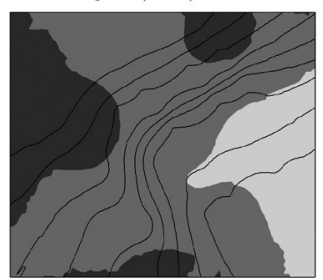

G. CEC (mmole $\left.\mathbf{d m}^{-3}\right)$ $60^{9} \cdot 60^{5}+0^{5}+0^{2}$

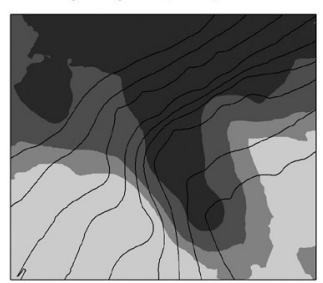

B. $\mathrm{Al}^{3+}\left(\mathrm{mmol}_{\mathrm{c}} \mathrm{dm}^{-3}\right)$ $0 \hat{0}^{\lambda} a^{x} 2^{3 x} 3^{5}$

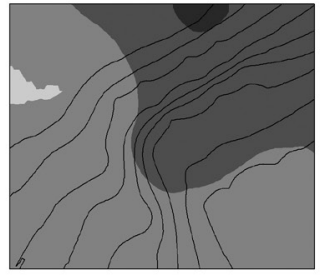

E. $\mathrm{Ca}^{2+}\left(\mathrm{mmol}_{\mathrm{c}} \mathrm{dm}^{-3}\right)$
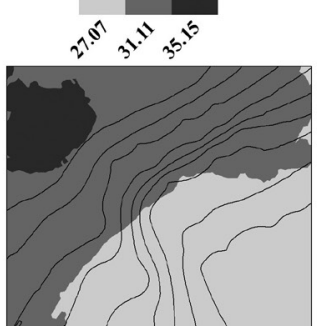

H. OM $\left(\mathrm{g} \mathrm{kg}^{-1}\right)$

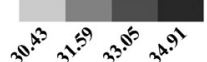

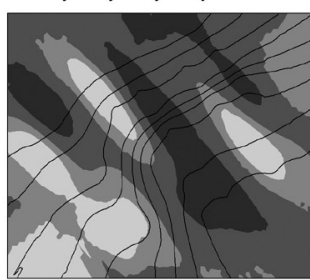

Scale 1:450

C. $\mathrm{H}+\mathrm{Al}\left(\mathrm{mmol}_{\mathrm{c}} \mathrm{dm}^{-3}\right)$ $30^{30} 3^{30^{6}} 3^{90^{2}} \times 0^{9^{x}}$

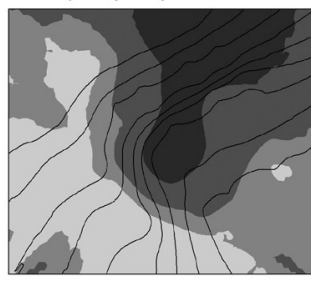

$\mathrm{Mg}^{2+}\left(\mathbf{m m o l}_{\mathbf{c}} \mathbf{d m}^{-3}\right)$ $3^{90} 6^{80} \hat{n}^{10}$

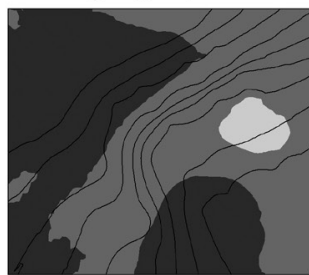

I. $P\left(\mathbf{m g ~ d m}^{-3}\right)$

$5 ?^{9} 60^{6} 40^{2}$

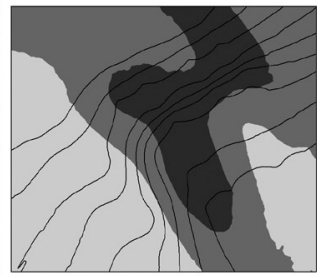

km

Figure 3. Spatial distribution of the chemical attributes of the soil in the study area in DU2 using ordinary kriging.

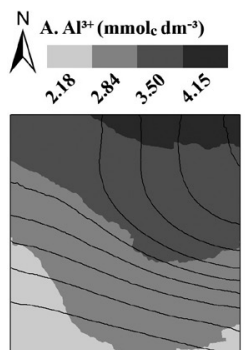

E. $\mathrm{Mg}^{2+}\left(\mathrm{mmol}_{\mathbf{c}} \mathrm{dm}^{-3}\right)$

$3^{x^{3}} x^{2}$

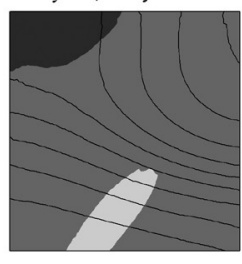

\section{C. $\mathrm{K}^{+}\left(\mathbf{m m o l}_{\mathbf{c}} \mathbf{d m}^{-3}\right)$}

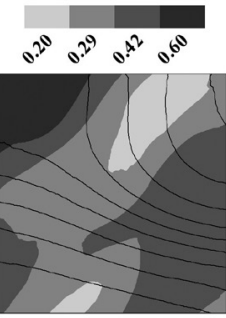

G. OM $\left(\mathrm{g} \mathrm{kg}^{-1}\right)$

F. CEC $\left(\mathbf{m m o l}_{\mathbf{c}} \mathbf{d m}^{-3}\right)$
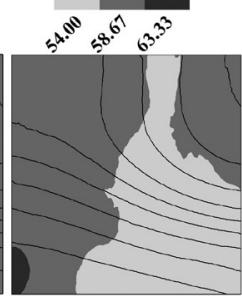

Scale 1:4200
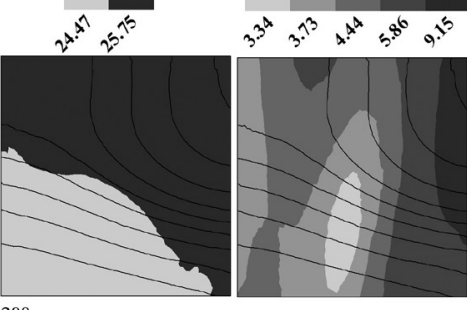

D. $\mathrm{Ca}^{2+}\left(\mathrm{mmol}_{\mathrm{c}} \mathrm{dm}^{-3}\right)$

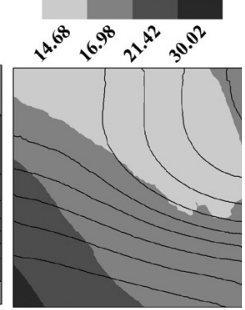

H. P $\left(\mathrm{mg} \mathrm{dm}^{-3}\right)$

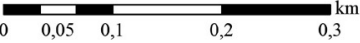

Figure 4. Spatial distribution of the chemical attributes of the soil in the study area in DU3 using ordinary kriging. 

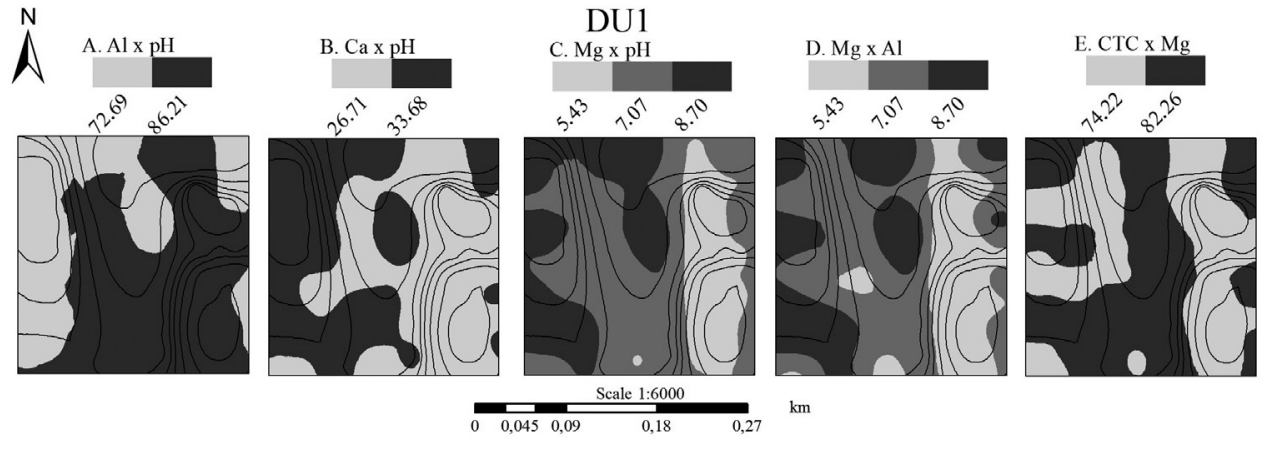

$\mathrm{km}$
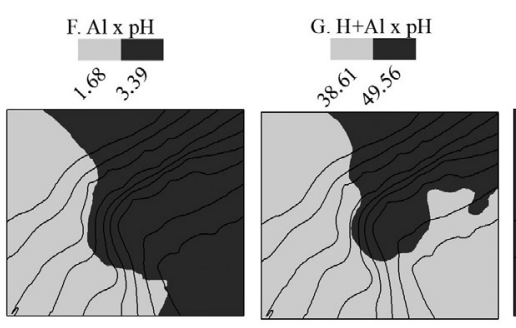

\section{DU2}
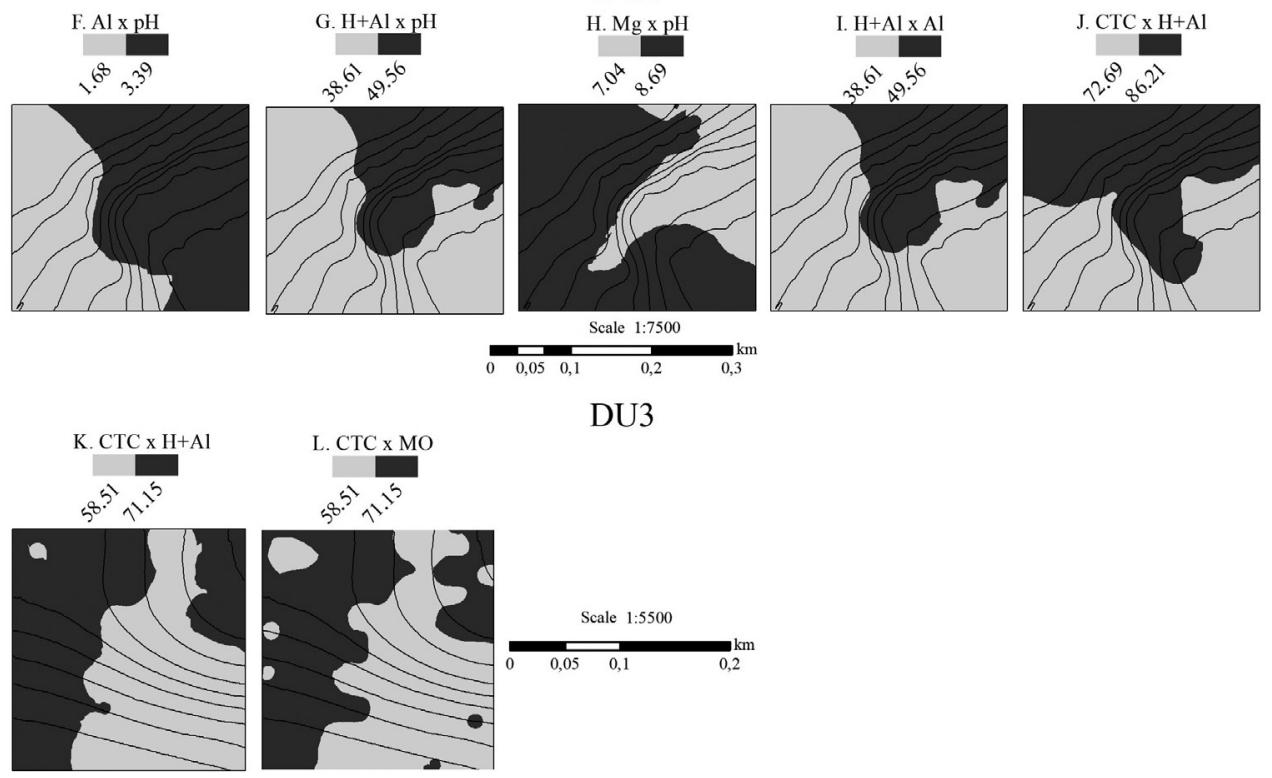

$$
\text { (n) }
$$
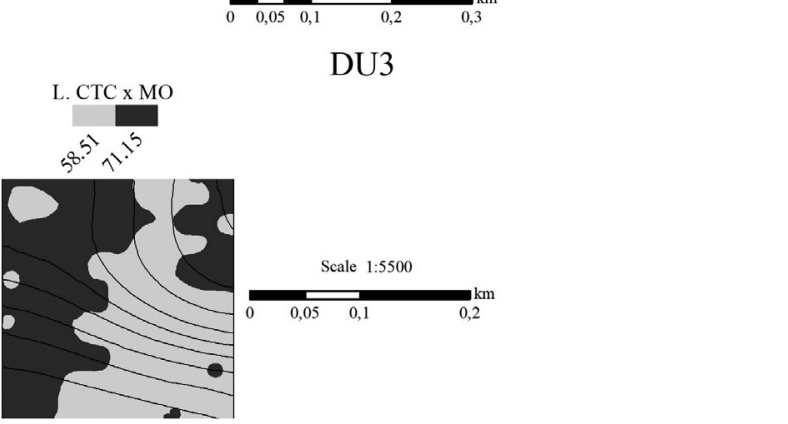

Figure 5. Spatial distribution of chemical characteristics of the soil estimated by cokriging in the study areas in three demonstrative units (DU1, DU2 and DU3).

sites and/or decrease the distance between sites, or apply other deterministic methods, including the inverse square distance (ISD) interpolation (Yamamoto and Landim 2013). A strong spatial dependence for soil attributes is observed in pedogenesis (Guerreiro et al. 2017). A moderate spatial dependence occurs in soils that are not homogeneous, and a weak spatial dependence may occur in areas that undergo extrinsic activities (Cambardella et al. 1994).

Guerreiro et al. (2017) analyzed the distribution of soil nutrients in the Tapajós National Forest using geostatistics, and adjusted the exponential model for $\mathrm{pH}\left(\mathrm{H}_{2} \mathrm{O}\right)$ and zinc, the Gaussian model for phosphorus and copper, and the spherical model for potassium and manganese. All of these chemical attributes presented a moderate spatial dependence, while carbon, nitrogen, sodium, calcium, magnesium, aluminum, and iron showed no spatial dependence, which differs from the results in this study. The authors suggest that PNE occurs because the spacing between samples is larger than necessary to detect spatial dependence.
In young soils, $\mathrm{pH}$ is higher due to the release of monovalent and divalent cations, whereas $\mathrm{Al}^{3+}$, the trivalent cation, remains at low levels in the soil solution. As the soils age, $\mathrm{Al}^{3+}$ remains in mineral form, and its hydrolysis interferes with $\mathrm{pH}$ (Quesada et al. 2010), justifying the correlation found between $\mathrm{pH}$ and $\mathrm{Al}^{3+}$ in the present study. The highest levels of $\mathrm{K}^{+}, \mathrm{Ca}^{2+}, \mathrm{Mg}^{2+}$ and OM (in DU1 and DU2), and $\mathrm{Al}^{3+}$ and $\mathrm{H}+\mathrm{Al}$ (in DU3) in lower areas of the study areas may be related to the topography and source material, which define the action and intensity of soil formation factors, as well as the distribution of soil attributes (Fontana et al. 2014). For example, cations may leach from higher areas to lower areas (Meireles et al. 2012).

Mantovanelli et al. (2016) evaluated the spatial distribution of soil acidity in a natural environment in Humaitá, in Amazonas state, and observed an irregular distribution of $\mathrm{H}+\mathrm{Al}$ and $\mathrm{Al}^{3+}$ along the topography, which contrasts with our results. However, Santos et al. (2008) evaluated how topography, soil texture, and land use affected the levels of 
extractable phosphorus, alkalinity, and exchangeable acidity in Paraíba state, in semiarid northeastern Brazil, and observed that the levels of $\mathrm{Ca}^{2+}, \mathrm{K}^{+}$and $\mathrm{H}+\mathrm{Al}$ were homogeneous along the topography, and that levels of $\mathrm{P}, \mathrm{Mg}^{2+}$ and $\mathrm{Na}^{+}$were higher in the lower areas.

The higher homogeneity of the soil attributes in DU3 as compared to DU1 and DU2 may have been due to the smaller altitude variation and the presence of unweathered and homogeneous soil in DU3. More heterogeneous soils and greater variation in altitude increase spatial variability in DU1 and DU2, so that the number of sampling points probably needs to be increased in these sites, and sampling intervals should agree with the range of each variable, as proposed by Montanari et al. (2008).

Souza et al. (2008) analyzed the spatial distribution of chemical characteristics of a Red-Yellow Argisol under pasture and observed a heterogeneous distribution of edaphic properties, corroborating our results. Dalchiavon et al. (2012) studied the spatial variability of the chemical characteristics of a Red Latosol with homogeneous topography and found a similar pattern to that of our study, including the homogeneous distribution of $\mathrm{OM}, \mathrm{Ca}^{2+}$ and $\mathrm{Mg}^{2+}$.

The low DSD of the cross semivariograms, which allowed an adjustment of the theoretical models and the estimation of primary variables based on the distribution of secondary variables, has the potential to reduce the cost of analyses. $\mathrm{pH}$ was the secondary variable with the highest number of correlations because of its relation with nutrient availability in the soil (Sousa et al. 2007). In addition, measuring $\mathrm{pH}$ is easy and unexpensive. The CEC was estimated by measuring the $\mathrm{OM}, \mathrm{H}^{+} \mathrm{Al}$, and $\mathrm{Mg}^{2+}$ because the $\mathrm{CEC}$ is determined by the sum of all bases, exchangeable acidity $\left(\mathrm{Al}^{3+}\right)$, and potential acidity. OM was correlated with CEC due to the activity of microorganisms, which increase the availability of nutrients such as $\mathrm{K}, \mathrm{Ca}^{2+}$, and $\mathrm{Mg}^{2+}$, allowing the $\mathrm{OM}$ to increase the CEC of the soil (Melo et al. 2008).

Similar results were obtained by Bottega et al. (2011), who estimated the levels of $\mathrm{Ca}^{2+}$ and $\mathrm{Mg}^{2+}$ as a function of $\mathrm{pH}$ using cokriging in a Red Latosol. The authors found a strong spatial dependence between $\mathrm{pH}$ and $\mathrm{Ca}(\mathrm{DSD}=16.1 \%)$ and between $\mathrm{pH}$ and $\mathrm{Mg}(\mathrm{DSD}=15.8 \%)$, indicating the possibility of using $\mathrm{pH}$ to estimate $\mathrm{Ca}^{2+}$ and $\mathrm{Mg}^{2+}$ in unsampled sites in the study area, reducing the costs of sampling and laboratory measurements. Dalchiavon et al. (2011) used $\mathrm{pH}$ as a covariable to explain the yield distribution of beans in a Distroferric Red Latosol, and observed a strong spatial dependence $(\mathrm{DSD}=0.16 \%)$, highlighting the use of $\mathrm{pH}$ as an indicator of bean productivity under a no-tillage system.

\section{CONCLUSIONS}

The chemical attributes of soil from agroforestry systems based on oil palm plantations in the eastern Brazilian Amazon were spatially dependent and correlated with one another. The results allowed the application of geostatistical techniques for the production of soil maps to support the management of the agroforestry systems. Cokriging was efficient in estimating chemical attributes that were difficult to determine in the laboratory as a function of easily determined variables.

\section{ACKNOWLEDGMENTS}

The authors thank Natura Cosméticos S.A. for making the data available for this study and Coordenaçáo de Aperfeiçoamento de Pessoal de Nível Superior - CAPES for financial support.

\section{REFERENCES}

Aquino, R.E.; Campos, M.C.C.; Marques Júnior, J.; Oliveira, I.A.; Mantovaneli, B.C.; Soares, M.D.R. 2014. Geoestatística na avaliação dos atributos físicos em Latossolo sob floresta nativa e pastagem na regiấo de Manicoré, Amazonas. Revista Brasileira de Ciência do Solo, 38: 397-406.

Bernardi, A.C.C.; Bettiol, G.M.; Grego, C.R.; Andrade, R.G.; Rabello, L.M.; Inamasu, R.Y. 2015. Ferramentas de agricultura de precisão como auxílio ao manejo da fertilidade do solo. Cadernos de Ciência \& Tecnologia, 32: 205-221.

Bottega, E.L.; Silva, S.A.; Costa, M.M.; Bottega, S.P. 2011. Cokrigagem na estimativa dos teores de $\mathrm{Ca}$ e $\mathrm{Mg}$ em um Latossolo Vermelho distroférrico. Revista Ciência Agronômica, 42: 821-828.

Cambardella, C.A.; Moorman, T.B.; Novak, J.M.; Parkin, T.B.; Karlen, D.L.; Turco, R.F.; Konopka, A.E. 1994. Field scale variability of soil properties incentral Iowa soils. Soil Science Society of American Journal, 58: 1501-1511.

Cavalcante, E.G.S.; Alves, M.C.; Souza, Z.M.; Pereira, G.T. 2011. Variabilidade espacial de atributos físicos do solo sob diferentes usos e manejos. Revista Brasileira de Engenharia Agrícola e Ambiental, 15: 237-243.

Dalchiavon, F.C.; Carvalho, M.P.; Andreotti, M.; Montanari, R. 2012. Variabilidade espacial de atributos da fertilidade de um Latossolo Vermelho Distroférrico sob Sistema Plantio Direto. Revista Ciência Agronômica, 43: 453-461.

Dalchiavon, F.C.; Carvalho, M.P.; Freddi, O.S.; Andreotti, M.; Montanari, R. 2011. Variabilidade espacial da produtividade do feijoeiro correlacionada com atributos químicos de um Latossolo Vermelho Distroférrico sob sistema de semeadura direta. Bragantia, 70: 908-916.

Fontana, A.; Pereira, M.G.; Anjos, L.H.C.; Santos, A.C.; Bernini, T.A. 2014. Matéria orgânica de horizontes superficiais em topolitossequências em ambiente de Mar de Morros, Pinheiral, RJ. Revista Ciência Agronômica, 45: 221-229.

Guerreiro, Q.L.M.; Oliveira Junior, R.C.; Santos, G.R.; Ruivo, M.L.P.; Beldini, T.P.; Carvalho, E.J.M.; Silva, K.E.; Guedes, M.C.; Santos, P.R.B. 2017. Spatial variability of soil physical and chemical aspects in a Brazil nut tree stand in the Brazilian Amazon. African Journal of Agricultural Research, 12: 237-250.

Mantovanelli, B.C.; Campos, M.C.C.; Alho, L.C.; Franciscon, U.; Nascimento, M.F.; Santos, L.A.C. 2016. Distribuição 
espacial dos componentes da acidez do solo em área de campo natural na regiẫo de Humaitá, Amazonas. Revista de Ciências Agroambientais, 14: 01-09.

Meireles, H.T.; Marques Júnior, J.; Campos, M.C.C.; Pereira, G.T. 2012. Relaçóes solo-paisagem em topossequência de origem basáltica. Pesquisa Agropecuária Tropical, 42: 129-136.

Melo, L.C.A.; Silva, C.A.; Dias, B.O. 2008. Caracterização da matriz orgânica de resíduos de origens diversificadas. Revista Brasileira de Ciência do Solo, 32: 101-110.

Montanari, R.; Pereira, G.T.; Marques Júnior, J.; Souza, Z.M.; Pazeto, R.J.; Camargo, L.A. 2008. Variabilidade espacial de atributos químicos em Latossolos e Argissolos. Ciência Rural, 38: 1266-1272.

Quesada, C.A.; Lloyd, J.; Schwarz, M.; Patiño, S.; Baker, T.R.; Czimczik, C.; et al. 2010. Variations in chemical and physical properties of Amazon forest soils in relation to their gensis. Biogeosciences, 7:1515-1541.

Ribeiro Júnior, P.J.; Diggle, P.J. 2001. geoR: a package for geostatistical analysis. R NEWS, 1: 15-18.

Ribeiro, R.C.; Lemos, W.P.; Bernardino, A.S.; Buecke, J.; Müller, A.A. 2010. Primeira ocorrência de Alcaeorrhynchus grandis (Dallas) (Hemiptera: Pentatomidae) predando lagartas desfolhadoras do dendezeiro no Estado do Pará. Neotropical Entomology, 39: 131-132.

Santiago, W.R.; Vasconcelos, S.S.; Kato, O.R.; Bispo, C.J.C.; RangelVasconcelos, L. G.T.; Castellani, D.C. 2013. Nitrogênio mineral e microbiano do solo em sistemas agroflorestais com palma de óleo na Amazônia oriental. Acta Amazonica, 43: 395-406.

Santos, A.C.; Salcedo, I.H.; Galvão, S.R.S. 2008. Relações entre uso do solo, relevo e fertilidade do solo em escala de microbacia. Revista Brasileira de Engenharia Agrícola e Ambiental, 12: 458-464.
Santos, H.G.; Jacomine, P.K.T.; Anjos, L.H.C.; Oliveira, V.A.; Lumbreras, J.F.; Coelho, M.R.; Almeida, J.A.; Cunha, T.J.F.; Oliveira, J.B. 2013. Sistema Brasileiro de Classificação de Solos. Embrapa, Brasília, Distrito Federal, 353p.

Schaffrath, V.R.; Tormena, C.A.; Fidalski, J.; Gonçalves, A.C.A. 2008. Variabilidade e correlação espacial de propriedades físicas de solo sob plantio direto e preparo convencional. Revista Brasileira de Ciência do Solo, 32: 1369-1377.

Silva, F.L.; Homma, A.K.O.; Pena, H.W.A. 2011. O cultivo de dendezeiro na Amazônia: promessa de um novo ciclo econômico na região. Observatorio de la Economia Latinoamericana, 158: $1-24$.

Sousa, D.M.G.; Miranda, L.N.; Oliveira, S.A. 2007. Acidez do solo e sua correção. In: Novais, R.F.; Alvarez, V.H.; Barros, N.F.; Fontes, R.L.F.; Cantarutti, R.B.; Neves, J.C.L. (Ed.). Fertilidade do solo. Sociedade Brasileira de Ciência do Solo, Viçosa, Minas Gerias, p.205-274.

Souza, G.S.; Lima, J.S.S.; Silva, S.A.; Oliveira, R.B. 2008. Variabilidade espacial de atributos químicos em um Argissolo sob pastagem. Acta Scientiarum Agronomy, 30: 589-596.

Warrick, A.W.; Nielsen, D.R. 1980. Spatial variability of soil physical properties in the field. In: Hillel, D. (Ed.). Applications of soil physics. Academic Press, Cambridge, p.319-344.

Watanabe, J.; Yamamoto, J.K.; Rocha, M.M.; Fonseca, P.P. 2009. Estudo da influência da correlaçáo inicial entre variáveis nos resultados de co-estimativas. Geociências, 28: 467-484.

Yamamoto, J.K.; Landim, P.M.B. 2013. Geoestatística: conceitos e aplicaçôes. Oficina de Textos, São Paulo, 215p.

RECEIVED: $02 / 12 / 2017$

ACCEPTED: $17 / 07 / 2018$

ASSOCIATE EDITOR: André B. Junqueira 
SUPPLEMENTARY MATERIAL (only avaliable in the electronic version)

SILVA et al. Spatial dependency and correlation of properties of soil cultivated with oil palm, Elaeis guineensis, in agroforestry systems in the eastern Brazilian Amazon

Table S1. Semivariogram of organic matter (OM) before exclude some outliers in Tomé-Açu, Pará, Brazil.

\begin{tabular}{|c|c|c|}
\hline \multirow{2}{*}{ Statistics } & \multicolumn{2}{|c|}{$\mathrm{OM}\left(\mathrm{g} \mathrm{kg}^{-1}\right)$} \\
\hline & DU2 ${ }^{5}$ & DU3 ${ }^{6}$ \\
\hline $\mathrm{C}_{0}{ }^{1}$ & 34.27 & 9.98 \\
\hline$\left(C_{0}+C\right)^{2}$ & 34.27 & 12.03 \\
\hline$a^{3}$ & 0.00 & 117.46 \\
\hline $\mathrm{DSD}^{4}(\%)$ & 100.00 & 82.96 \\
\hline Class & $\mathrm{PNE}^{7}$ & Weak \\
\hline Model & - & Spherical \\
\hline
\end{tabular}

${ }^{1}$ Nugget effect; ${ }^{2}$ Sill; ${ }^{3}$ Range; ${ }^{4}$ Degree of spatial dependence; ${ }^{5}$ Demonstrative unit $2 ;{ }^{6}$ Demonstrative unit $3 ;{ }^{7}$ Pure nugget effect.

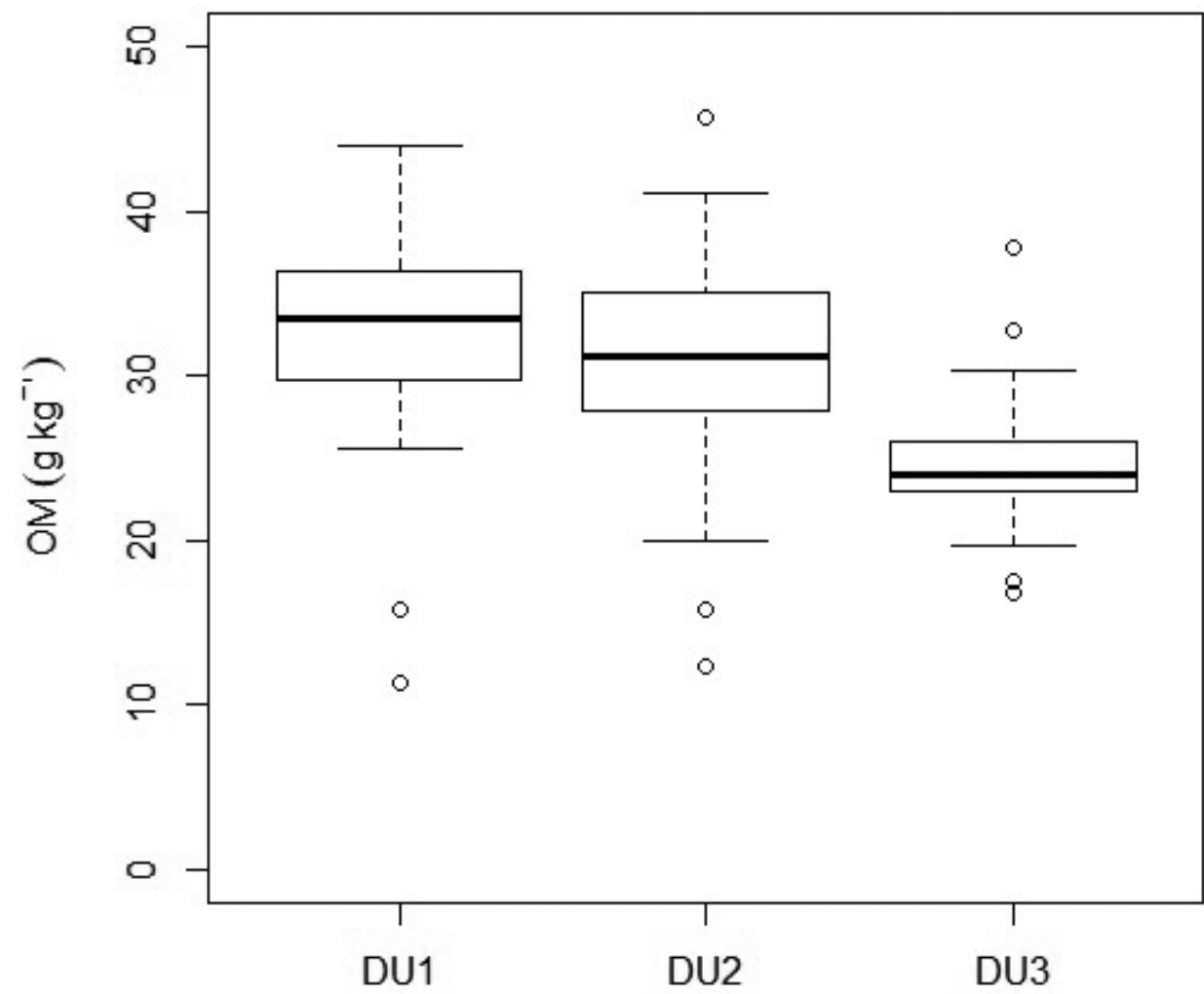

Figure S1. Boxplot of the organic matter values of soil samples from three study areas (DU1, DU2 and DU3) in an agroforestry systems containing oil palm plantations in Tomé-Açu, Pará, Brazil. 


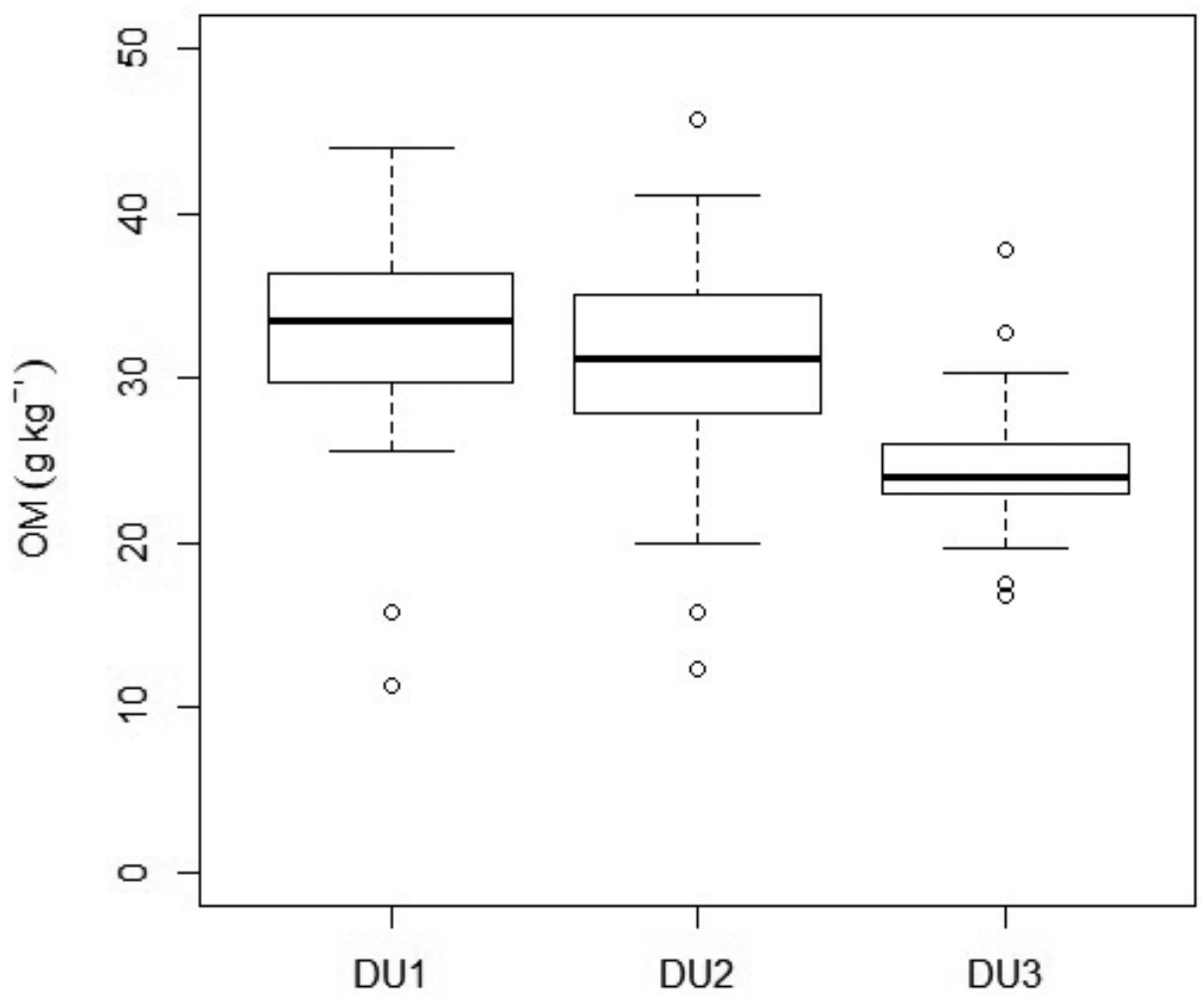

Figure S2. Boxplot of calcium and phosphorus values in soil samples from one study area (DU2) in an agroforestry systems containing oil palm plantations in ToméAçu, Pará, Brazil.
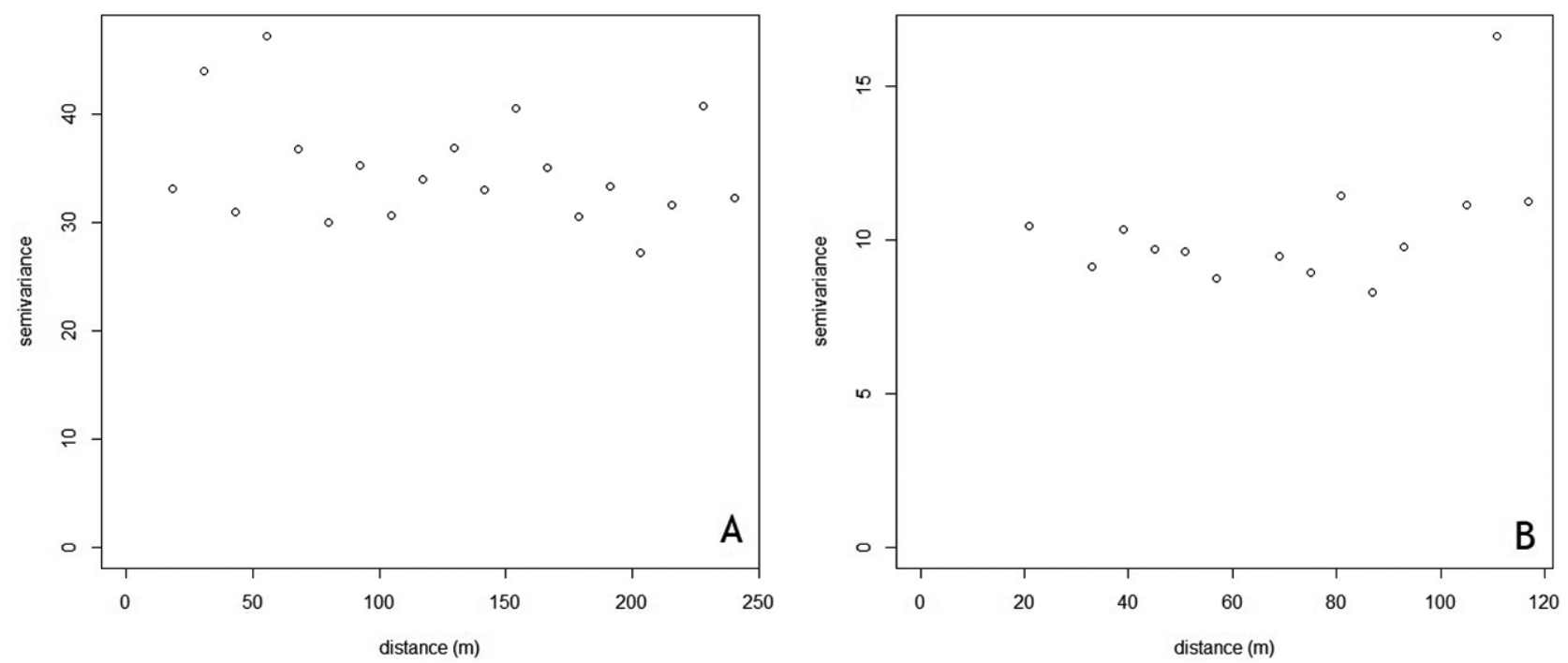

Figure S3. Semivariogram graphics (prior to removal of outliers) of organic matter values in soil samples from two study areas, DU2 (A) and DU3 (B), in agroforestry systems containing oil palm plantations in Tomé-Açu, Pará, Brazil. 